\title{
Reflection on consumers in e-Commerce
}

\section{Reflexión de los consumidores en el comercio electrónico}

GONZÁLEZ-CASTOLO, Juan Carlos †๋*, RAMOS-CABRAL, Silvia and ZATARAIN-DURÁN, Omar Alí

Universidad de Guadalajara, Mexico.

ID $1^{\text {st }}$ Author: Juan Carlos, González-Castolo / ORC ID: 0000-0003-2659-0646, Researcher ID Thomson: R-5580-2018

ID $1^{\text {st }}$ Coauthor: Silvia, Ramos-Cabral / ORC ID: 0000-0003-4204-1700, Researcher ID Thomson: R-7124-2018

ID $2^{\text {nd }}$ Coauthor: Omar Alí, Zatarain-Durán / ORC ID: 0000-0002-7934-7765, Researcher ID Thomson: E-2222-2019

DOI: $10.35429 / J B A B .2020 .6 .4 .23 .31$

Received January 15, 2020; Accepted June 30, 2020

\begin{abstract}
This paper presents a reflection on the ideal requirements that a provider should offer to the consumer. Traditionally, studies are made to improve products and/or services, but the consumer's point of view is disesteemed. This work approaches the commerce scenario from an approach where the consumer is the protagonist. The context of analysis is electronic commerce (e-commerce), however, the approaches can be extended to traditional commerce. It should be noted that commerce can be classified as traditional or electronic. In the specific area of $e$ commerce, it is known that the relevant defining characteristic is the use of information and communication technologies (ICT). Due to the above, the consumer has some particularities that are considered to present the approach. It is about identifying the elements for $e$ commerce improvement. Improving the sale-purchase cycle that includes improving marketing, improving consumer service, improving the product and/or service offered, and the improvement of the WEB portal.
\end{abstract}

e-Commerce, ICT, Consumer

\begin{abstract}
Resumen
En este trabajo se presenta una reflexión sobre los requerimientos ideales que un proveedor debe ofrecer al consumidor. Tradicionalmente se hacen estudios de mejora de productos y/o servicios sin embargo se desestima el punto de vista del consumidor. Este trabajo aborda el escenario de comercio desde un enfoque donde el consumidor es el protagonista. El contexto de análisis es el comercio electrónico (e-comercio), sin embargo, los planteamientos pueden extenderse al comercio tradicional. Cabe puntualizar que el comercio puede clasificarse como tradicional o electrónico. En el área específica del $e$ comercio, se sabe que la característica relevante que lo define es el uso de las tecnologías de información y comunicación (TIC). Debido a lo anterior, el consumidor tiene algunas particularidades que son tomadas en cuenta para presentar el enfoque. Se trata de identificar los elementos para mejorar el e-comercio. Mejora del ciclo de compra-venta que incluye la mejora del mercadeo, la mejora del servicio de atención el consumidor, la mejora del producto y/o servicio ofrecido y la mejora del portal WEB.
\end{abstract}

Comercio electrónico, TIC, Consumidor

Citation: GONZÁLEZ-CASTOLO, Juan Carlos, RAMOS-CABRAL, Silvia and ZATARAIN-DURÁN, Omar Alí. Reflection on consumers in e-Commerce. Journal-Business Administration-Marketing; Accounting. 2020. 4-6:23-31.

\footnotetext{
* Correspondence to Author (Email: jcgcastolo@ hotmail.com)

$\dagger$ Researcher contributing first author.
} 


\section{Introduction}

In recent years, the use of digital services has increased (Anissa, Purwandari, Wilarso, \& Sensuse) such as electronic bank (LiébanaCabanillas, Muñoz-Leiva, Sánchez-Fernández, \& Viedma-del Jesús, 2016), electronic billing (O'Leary, 2000), electronic citizen services (Kotsuka, Murakami, \& Arima, 2019), electronic medical assistance (Wrenn, Catschegn, Cruz, Gleason, \& Gonzales, 2017), electronic education (MD, CCFP, Ratnapalan, Lam-Antoniades, \& Tait, 2009), electronic administration (Collins, 2008), e-commerce (Linwan, 2019) (Blazquez, Zhang, Boardman, \& Henninger, 2019) (Adaji, Oyibo, \& Vassileva, 2018), etc.

The extensive use of the ICT has a great impact on business, organizations and $e$ commerce transaction because is as a highway that facilitates the massive communication breaking the barrier of distance and time (Dhamacharoen, Kumpusiri, \& Waiyakarn, 2019). ICT allows companies to make innovative proposals that help them achieve good economic results and grow too. (Jimenez Villalba \& Moreno Acevedo, 2020). The use of ICT senerates a large amount of data where their analysis can reveal trade trends (Amado, Cortez, Rita, \& Moro, 2018), volume productions (Tekin, Etlioglu, Koyuncuoğlu, \& Tekin, 2018), personalized marketing (Behera, Gunasekaran, Gupta, \& Kamboj , 2019). Furthermore, the knowledge extracted from the data can be used to provide guidelines for improving WEB use of e-commerce and user satisfaction (Carmona, Ramírez-Gallego, Torres Ruiz, \& Bernal, 2012).

The history of anthropology, sociology and cultural studies motivated an interdisciplinary study that show consumption as a dynamic field that is nourished by all disciplines (Aristizábal García, 2020). In the context of e-commerce, there is a wide variety of scientific research and interest in the subject (Lingyun \& Dong, 2008) (Luo, Xu, \& Yao, 2012). To understand user's behavior, some researchers have focused on psychological models that could simulate consumer's thoughts (Shen, Zhou, Xu, Hu, \& Hu, 2009).
Several factors, such as reliability, website quality, perceived risk in the transaction, customer satisfaction, among others, affect the consumer's intention at the time of electronic purchase (Anissa, Purwandari, Wilarso, \& Sensuse), another important aspect of the study that should to be considered is the security of the transaction (Ilmudeen , 2019). The critical moment of care occurs during the purchase-sale (Barkatullah \& Djumadi , 2018). Some studies affirm that the future of e-commerce depends on the development of extra-judicial mechanisms for conflict resolution adapted to internet dynamics. The mechanisms are called online dispute resolution (ODR) and they need capable of providing equal security and confidence to consumers and merchants, however, there is no agreed international ODR (González \& Nava González, 2020). The problem is notorious, for example, in Pacific Alliance (PA) that it was integrated with four Latin countries. However, the PA is far from achieving its objective of greater integration and economic growth in each country (Licona Michel, Rangel Delgado, \& González García, 2020). So, it is clear that one of the great problems in Latin America is the lack of comprehensive trade policy (Pesántez Calva, Romero Correa, \& González Illescas, 2020).

This study presents a reflection of the answer to the question: "What does the consumer want?". It shows light answers to other research questions, but it is important to mention them because they establish a basis for further study from the exposed approach in this work. desire?

How does marketing change consumer

How to cause the consumer to enter an avarice state?

This paper is organized as follow: In the next section, the theoretical framework is presented, followed by a review of the characteristics of consumer and provider in the e-commerce context. The reflection about: "What does the consumer want?" is presented and: "What does the electronic consumer want?" is also included. Finally, the conclusions are given. 


\section{Background}

A conceptual map is a tool of knowledge representation that resembles a bi-graph where each concept is a node. Arcs are used to relate concepts. The distribution of a conceptual map follows a logical link.

Figure shows that the concept $A * B$ is justified only if concepts $A, B$ are given previously and is reading as if $A$ and $B$ then $A * B$. Concepts $A, B$ and $C$ justify a concept that is explained by two background and this is interpreted as if $A$ and $B$ or $C$ then $(A * B)+t 1 C$.

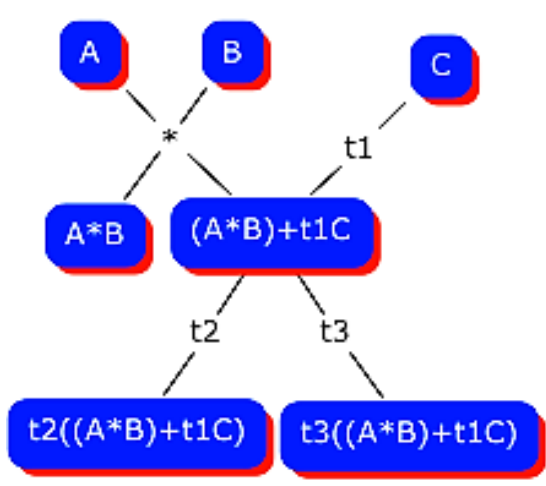

Figure 1 Logical concepts map

Source: (González-Castolo, Ramos-Cabral, \& Hérnandez-Gallardo, 2016)

\section{Definitions glossary}

Product (P): Something that is offered in a transaction purchase-sale to attend a real or potential necessity of an entity.

Entity (E): Organization (O) or individual (I), Eq1.

$\mathrm{E}=\mathrm{O} \cup \mathrm{I} \mid \mathrm{O}=\{\mathrm{I}\}$

Consumer (Cmer): An E that acquires a $\mathrm{P}$ through a purchase-sale transaction (pst).

Provider (Pder): An E that offers a $\mathrm{P}$ through a pst.

Consumer society: The consequent way in which $\mathrm{E}$ is related in a capitalist economic system.

Supply chain: This is referred to as the relations among E's to offer a $\mathrm{P}$ in the market.

Desire: A condition in which an $\mathrm{E}$ wants something and may become a need.
Necessity: A survival condition that approaching a perception of well-being.

Avarice state: Condition in which the Cmer buys a $\mathrm{P}$.

In the context of e-commerce, the Cmer and Pder are online consumer and provider. They are called as eConsumer (eCmer) and eProvider (ePder) respectively.

\section{eConsumers and eProvider}

The existence of $P$ is an elementary fact in a consumer society and therefore all $E$ is a Cmer and a Pder simultaneously, Eq2.

$E=$ Cmer $\cap$ Pder

The above is also true for a supply chain of a specific $P$ where there is an intermediary (Inter), Eq3.

$E^{P}=\operatorname{Cmer}^{P} \cap \operatorname{Pder}^{P} \mid \exists$ Inter $^{P} \in E$

The previous equation changes if a specific $P$ is for a final consumer (Cmerf) because the $E$ can only be a Cmer or a Pder, Eq4.

$E^{P}=\operatorname{Cmer}^{P} \cup \operatorname{Pder}^{P} \mid \operatorname{Cmerf}^{P} \in E$

In general, the $E$ can be a $P d e r$ or a $C m e r$ or both, Eq5.

$E=$ Pder $\cup$ Cmer $\cup($ Cmer $\cap$ Pder $)$

Figure 2 shows that $E$ could be $P d e r$ and Cmer at the same time. The Pder could attend more than one Cmer and more than one Pder could be attended for one Cmer.

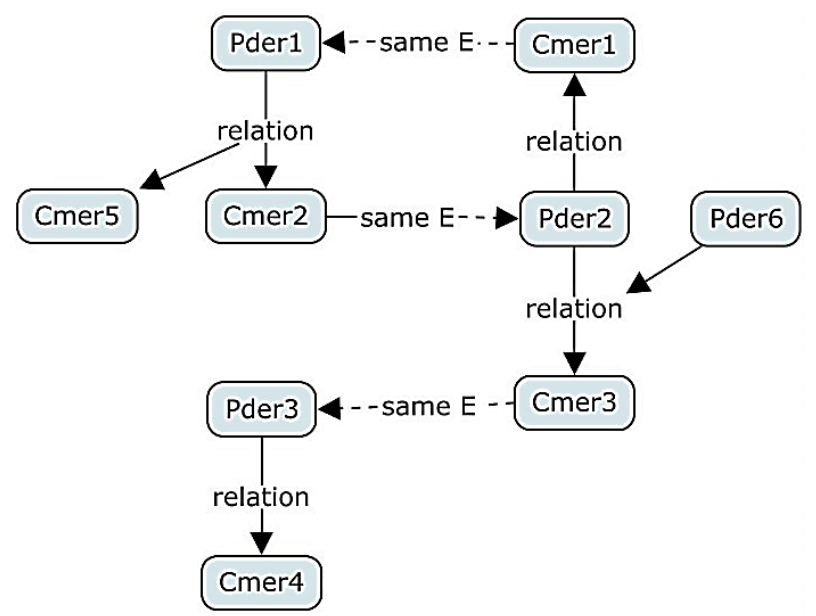

Figure 2 Provider \& consumer

Source: Own elaboration

GONZÁLEZ-CASTOLO, Juan Carlos, RAMOSCABRAL, Silvia and ZATARAIN-DURÁN, Omar Alí. Reflection on consumers in e-Commerce. JournalBusiness Administration-Marketing; Accounting. 2020 
Electronic entity (eE) is manifested in ecommerce and this is a subset of E, Eq6.

$e E \in E$

$e E=e C m e r \cup$ ePder $\cup($ eCmer $\cap e P d e r)$

Topics that are an important study in ecommerce are 1) offer, 2) marketing, and 3) security.

\section{Sale-purchase cycle}

Every $I$ has necessities and unfulfilled desires, then every $I$ is $C m e r$ and potential eCmer. Every I seeks to survive (care vital). The care vital induces a necessity. Every Cmer has a lifestyle that is stimulated by the social interaction and marketing.

The lifestyle induces the desire. Lifestyle can become care vital and desire can become a necessity. The desire and/or the necessity induce a problem and this, in turn, induce a search for solution in the market. The market is where $P d e r$ s that offer $P$ s are locaded. The $P$ s offered and the marketing induce an avarice state. The avarice state induces to take out a pst. After completing the pst, the $P$ is sent to the Cmer's address. After the Cmer has the $P$, he evaluates whether it provides a problem solution. If the $P$ is a problem's partial solution, then it induces a new solution search.

If the $P$ is a suitable solution to the problem, then it can end the sale-purchase cycle. However, the obtained solution can be transformed into a partial solution through marketing, lifestyle, and social interaction. Lifestyle is self-induced with the participation of social interaction and marketing. Marketing originates from both the Cmer (in a recommendation way) and the $P d e r$ (in a commercial disclosure strategy way), Fig. 3.

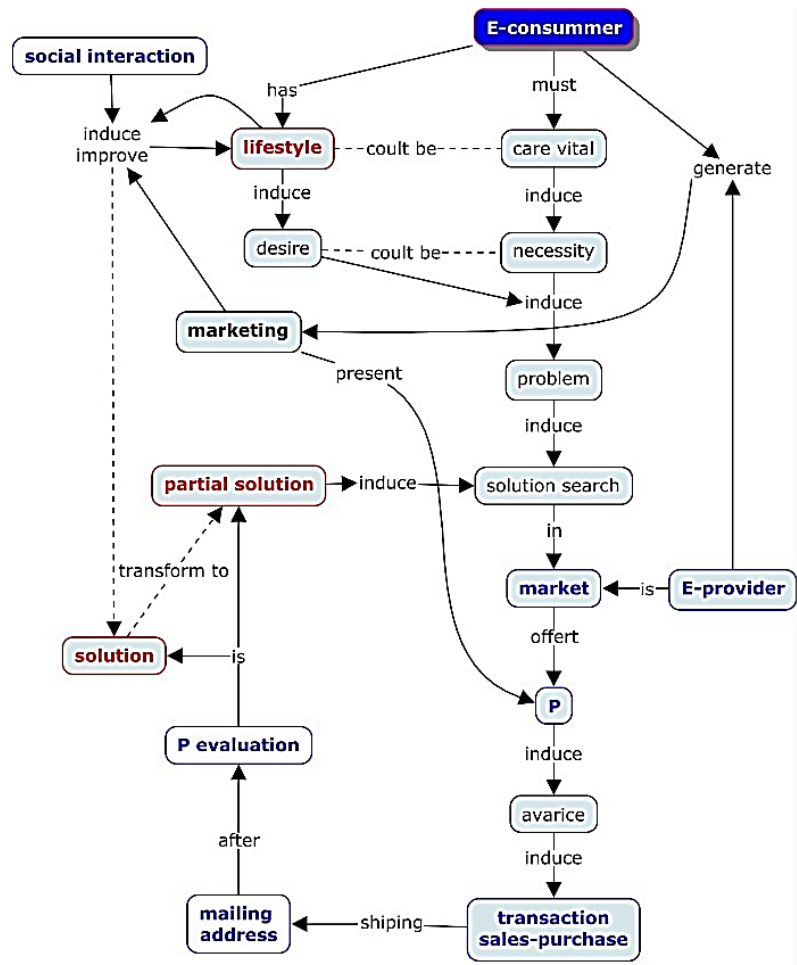

Figure 3 Sale-purchase cycle in e-commerce Source: Own elaboration.

The components in care vital are related to physiological needs as food, health, and dress. The lifestyle is related to psychological needs. Care vital could be seen as a lifestyle, and viceversa. The swap occurs in the I's head. The necessity and desire are equivalent in this condition. Then the psychological satisfaction is the principal component to attend in the consumer society. The $I$ wants to improve his condition and living space.

A $P$ is a satisfier. The $I$ buys satisfiers that do not attend the order of Maslow's pyramid. The marketing approach is oriented to offer elements to attend the top of that pyramid. The optimal goal of marketing is to maximize $I$ 's spending without harming his financial health.

The problems induced by necessity or desire are tangible or intangible. The tangible problem could be fixing a car or attending a physical condition. The intangible problem could be getting the latest smartphone or taking a vacation in an elegant place. A variety of $P$ exists to attend the problem total or partiality.

The Cmer wants the $P$ (solution) to attend to the problem in a simple, fast, efficient, optimal, and economic way. The simple solution is always better. The fast solution helps to eliminate the problem quickly. 
The efficient solution is that it eliminates the entire problem. The optimum solution is that there is no waste of $P$. The economic solution indicates that its value is much more expedient than the cost of the problem. $P$ 's price is regulated by marketing. Many $\mathrm{P}$ are integrated with surpluses that stimulate the ego-mind to sell at a high price. The social phycology stimulates the market but the marketing makes necessities. The consumption limit is set by money because the $I$ cannot be satisfied.

\section{What does the consumer want?}

The consumer society creates needs through marketing. The Cmer wants satisfaction before, during, and after purchase the $P$ and therefore improve their mood. But, what thing would improve the mood? For example, improve life quality, and social status, next, improve family conditions and social environment.

The consumer's ideal is to purchase a $P$ that provides pleasure indefinitely. The product must give pleasure since it is known, bought, and used (property).

A reasonable case is accepted when the Cmer buys a $P$ that has benefits it promises. The marketing says about these benefits. In this case, the message must be precise.

The general characteristics that the Cmer wants from the Pder are listed below:

Trustworthy. It means that Pder always complies with the rules of the sales-purchase process.

Honest. This characteristic is observed when the $P$ is faithfully described and does not hide something unfavorable for the Cmer.

Fair. It refers to the fact that there is no over-price of the $P$. Note: The $P$ could be the over-price but the Cmer must know it.

Attentive. This feature is shown when Pder solves the questions, eliminates worries and makes that Cmer feel that is important to have him as a client.

\section{What does the e-consumer want?}

In addition to the above, Cmer has additional requirements in the e-commerce scenario. Some ideal demands that $e$ Cmer wants to find in $\mathrm{ePder}$ are described. It is necessary to clarify that some of the requests may be more general.

Desirable characteristics in the sale-purchase transaction

The transaction is the most important event in the sales-purchase cycle. Security is the most notable feature in the transaction. It is referred as the certainty that the parties (eCmer, ePder) agree to respect the process rules of salepurchase. Clear rules are necessary in process violation case as product condition anomaly, product delivery time anomaly, payment method, and/or payment time. The e-commerce scenario is different from traditional because the transaction is paid first and the product is received commonly afterward.

\begin{tabular}{|c|c|c|}
\hline $\begin{array}{l}\text { Aspect of } \\
\text { security }\end{array}$ & $\begin{array}{c}\text { Recommended } \\
\text { Action }\end{array}$ & Justify \\
\hline $\begin{array}{l}\text { The payment } \\
\text { is channeled } \\
\text { to the ePder's } \\
\text { account }\end{array}$ & $\begin{array}{l}\text { Feedback on the } \\
\text { payment } \\
\text { transaction }\end{array}$ & $\begin{array}{l}\text { Immediate } \\
\text { attention when } \\
\text { some problem is } \\
\text { detected }\end{array}$ \\
\hline $\begin{array}{l}\text { The payment } \\
\text { operation }\end{array}$ & $\begin{array}{l}\text { Offer many forms } \\
\text { of payment and/or } \\
\text { one that must be } \\
\text { similar to giving } \\
\text { and receiving in a } \\
\text { traditional } \\
\text { transaction }\end{array}$ & $\begin{array}{l}\text { Avoid the risk } \\
\text { of credit or debit } \\
\text { card data usage } \\
\text { and/or the risk } \\
\text { to going a } \\
\text { physical } \\
\text { business } \\
\text { establishment to } \\
\text { pay }\end{array}$ \\
\hline $\begin{array}{l}\text { The ePder } \\
\text { agrees to has } \\
\text { received } \\
\text { payment for } \\
\text { a product }\end{array}$ & $\begin{array}{lr}\text { Feedback about } \\
\text { requisition status } \\
\text { and/or } \\
\begin{array}{l}\text { corresponding } \\
\text { payment }\end{array}\end{array}$ & $\begin{array}{l}\text { Avoid that } \\
e \text { Cmer from } \\
\text { getting nervous }\end{array}$ \\
\hline $\begin{array}{l}\text { The eCmer } \\
\text { receives } P \\
\text { with precise } \\
\text { conditions } \\
\text { according to } \\
\text { the offered } \\
\text { state }\end{array}$ & $\begin{array}{l}\text { The description of } \\
\text { the } P \text { must } \\
\text { accurately illustrate } \\
\text { its condition and } \\
\text { that such } \\
\text { information reaches } \\
\text { the } e \text { Cmer }\end{array}$ & $\begin{array}{l}\text { Prevents } \text { eCmer } \\
\text { from feeling } \\
\text { cheated }\end{array}$ \\
\hline $\begin{array}{l}\text { Transport is } \\
\text { transparent } \\
\text { in the sales- } \\
\text { purchase } \\
\text { operation for } \\
\text { the } e \text { Cmer }\end{array}$ & $\begin{array}{l}\text { The purchase-sale } \\
\text { operation must } \\
\text { satisfactorily } \\
\text { compensate for any } \\
\text { inconvenience or } \\
\text { damage suffered by } \\
\text { the product in its } \\
\text { transportation, as } \\
\text { well as any } \\
\text { inconvenience for } \\
\text { the delay }\end{array}$ & $\begin{array}{l}\text { Avoid anything } \\
\text { with } \\
\text { transportation } \\
\text { because it gets } \\
\text { the eCmer tired }\end{array}$ \\
\hline
\end{tabular}

GONZÁLEZ-CASTOLO, Juan Carlos, RAMOSCABRAL, Silvia and ZATARAIN-DURÁN, Omar Alí. Reflection on consumers in e-Commerce. JournalBusiness Administration-Marketing; Accounting. 2020 


\begin{tabular}{|l|l|l|}
\hline Satisfaction & $\begin{array}{l}\text { Possibility of } \\
\text { returning the P } \\
\text { easily and without } \\
\text { additional charge to } \\
\text { the } e \text { Cmer }\end{array}$ & $\begin{array}{l}\text { Many } P \text { must be } \\
\text { physically } \\
\text { appreciated ach as } \\
\text { such } \\
\text { clothing, food, } \\
\text { perfume, etc. }\end{array}$ \\
\hline
\end{tabular}

Table 1

Some other features besides security.

\begin{tabular}{|c|c|c|}
\hline Ideal aspect & $\begin{array}{l}\text { Recommended } \\
\text { Action }\end{array}$ & Justify \\
\hline $\begin{array}{l}\text { The } P \text { is } \\
\text { obtained right } \\
\text { now }\end{array}$ & $\begin{array}{l}\text { Manage the } \\
\text { shipping schedule } \\
\text { by } e \text { Cmer }\end{array}$ & $\begin{array}{l}\text { The action must } \\
\text { be efficient as } \\
\text { the payment is } \\
\text { made }\end{array}$ \\
\hline Easy payment & 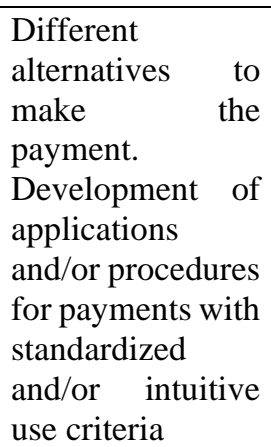 & $\begin{array}{l}\text { Avoid tiring the } \\
e \text { Cmer with the } \\
\text { process }\end{array}$ \\
\hline $\begin{array}{l}\text { Easy tracking } \\
\text { and/or } P \text { 's } \\
\text { location }\end{array}$ & $\begin{array}{l}\text { Development of } \\
\text { tutorials and } \\
\text { recommendations } \\
\text { to use app and/or } \\
\text { portals web }\end{array}$ & $\begin{array}{l}\text { Avoid eCmer's } \\
\text { nervousness } \\
\text { about the } P \\
\text { situation }\end{array}$ \\
\hline $\begin{array}{l}\text { Easy exchange } \\
\text { or refund }\end{array}$ & $\begin{array}{l}\text { The money back } \\
\text { and/or product } \\
\text { return process } \\
\text { should be simple }\end{array}$ & $\begin{array}{l}\text { Guarantee } P^{`} \mathrm{~s} \\
\text { satisfaction and } \\
\text { avoid } \\
\text { frustration } \\
\text { and/or } \\
\text { disappointment. }\end{array}$ \\
\hline $\begin{array}{l}\text { Easy } \\
\text { communication } \\
\text { with the } e P d e r\end{array}$ & $\begin{array}{l}\text { Guarantee } \\
\text { satisfaction of } \mathrm{P} \\
\text { and avoid } \\
\text { frustration and/or } \\
\text { disappointment. }\end{array}$ & $\begin{array}{l}\text { Trust is } \\
\text { fostered, which } \\
\text { is a complement } \\
\text { to satisfy the } \\
\text { shopping } \\
\text { pleasure of } \\
\text { eCmer's }\end{array}$ \\
\hline
\end{tabular}

Table 2

\section{Desirable market characteristics (Offer)}

The buying and selling cycle has an addictive and stress component. The stress component is due to the uncertainty of the functionality of the product, the expense of money, the interaction with the supplier, the purchase-sale process, etc. The addictive component is due to novel experience, pleasant associated memories etc. The functionality of the product refers to the quantity and magnitude that stimulate the senses in a pleasant way and/or that satisfy the psychological state.

\begin{tabular}{|c|c|c|}
\hline Ideal aspect & $\begin{array}{l}\text { Recommended } \\
\text { Action }\end{array}$ & Justify \\
\hline $\begin{array}{l}\text { After-sales } \\
\text { support }\end{array}$ & $\begin{array}{l}\text { Any concern } \\
\text { and/or doubt of } \\
e C m e r \text { about } P \text {, be } \\
\text { addressed } \\
\text { immediately }\end{array}$ & $\begin{array}{l}\text { Increment the } \\
\text { satisfaction } \\
\text { that has } P\end{array}$ \\
\hline $\begin{array}{l}\text { Locate any } P \\
\text { easily that could } \\
\text { help solve the } \\
\text { problem solve }\end{array}$ & $\begin{array}{l}\text { The WEB portal } \\
\text { must be adaptable } \\
\text { to the search for } \\
\text { eCmer's solutions }\end{array}$ & $\begin{array}{l}\text { Provide } \\
\text { solutions to } \\
\text { the problem }\end{array}$ \\
\hline $\begin{array}{l}\text { Easily } \\
\text { Comparison of } \\
P \text { prices and } \\
\text { benefits }\end{array}$ & $\begin{array}{l}\text { Development of } \\
\text { functions to make } \\
\text { comparisons } \\
\text { and/or adaptable } \\
\text { filters to eCmers }\end{array}$ & $\begin{array}{l}\text { Facilitate } \\
\text { choice P }\end{array}$ \\
\hline $\begin{array}{l}\text { Easy recreation } \\
\text { of } P \text { in the } \\
\text { environment of } \\
\text { use }\end{array}$ & $\begin{array}{l}\text { Use of virtual } \\
\text { and/or augmented } \\
\text { reality; use of tools } \\
\text { for superimposes } \\
\text { the product on an } \\
\text { image loaded by } \\
\text { eCmer }\end{array}$ & $\begin{array}{l}\text { It helps to } \\
\text { increase the } \\
\text { pleasure to } \\
\text { buy and } \\
\text { guarantees the } \\
\text { pleasure of } \\
\text { having the } \\
\text { product after } \\
\text { purchase }\end{array}$ \\
\hline $\begin{array}{l}\text { Notifications } \\
\text { decision about } \\
\text { improvements } \\
\text { of } P \text { and/or new } \\
\text { related } P \text { s }\end{array}$ & $\begin{array}{l}\text { Pop-up windows } \\
\text { or message }\end{array}$ & $\begin{array}{l}\text { It is respectful } \\
\text { because it } \\
\text { recognizes the } \\
\text { decision of } \\
\text { eCmer }\end{array}$ \\
\hline $\begin{array}{l}\text { Personalized } \\
\text { attention }\end{array}$ & $\begin{array}{l}\text { The use of } \\
\text { artificial } \\
\text { intelligent }\end{array}$ & $\begin{array}{l}\text { It helps to } \\
\text { increase the } \\
\text { eCmer's } \\
\text { pleasure to } \\
\text { buy }\end{array}$ \\
\hline $\begin{array}{l}\text { Unlimited } \\
\text { warranty }\end{array}$ & $\begin{array}{l}\text { Take the old } \\
\text { product when } \\
\text { buying a new one }\end{array}$ & $\begin{array}{l}\text { The eCmer } \\
\text { will feel that } \\
\text { he/she is } \\
\text { always } \\
\text { winning } \\
\text { and/or does } \\
\text { not lose }\end{array}$ \\
\hline
\end{tabular}

Table 3

\section{Desirable characteristics of the P (Demand)}

In order to give satisfaction (tangible and/or intangible) to eCmer, the product benefits must be cheap, durable, and practical. These characteristics are relative because they depend of time, situation, and each individual. 


\begin{tabular}{|l|l|l|}
\hline \multicolumn{2}{|c|}{ Ideal aspect } & \multicolumn{1}{c|}{$\begin{array}{l}\text { Recommended } \\
\text { Action }\end{array}$} \\
\hline Easy to use & $\begin{array}{l}\text { Applied } \\
\text { ergonomic } \\
\text { features and/or } \\
\text { providing } \\
\text { resources to } \\
\text { learn how to use } \\
\text { it }\end{array}$ & $\begin{array}{l}\text { eCmer enjoys } \\
\text { using it }\end{array}$ \\
\hline $\begin{array}{l}\text { That delights the } \\
\text { senses like } \\
\text { touch, sight, } \\
\text { hearing, smell } \\
\text { and taste }\end{array}$ & $\begin{array}{l}\text { The } \\
\text { development of } \\
\text { technology that } \\
\text { recreates the } \\
\text { characteristics } \\
\text { of the product }\end{array}$ & $\begin{array}{l}\text { eCmer enjoys } \\
\text { buying it }\end{array}$ \\
\hline $\begin{array}{l}\text { That strengthens } \\
\text { and/or improves } \\
\text { the social } \\
\text { position }\end{array}$ & $\begin{array}{l}\text { Pay attention so } \\
\text { that marketing } \\
\text { makes the } \\
\text { difference }\end{array}$ & $\begin{array}{l}\text { having it enjoys } \\
\text { hater the }\end{array}$ \\
\hline
\end{tabular}

Table 4

\section{Desirable eCmer's sensations}

In summary, $e$ Cmer wants $P$ to satisfy his needs and/or desires. Also, eCmer wants to feel important, that someone understands his life vision and dreams, that someone attends his questions.

\section{- $\quad$ Satisfaction to search P.}

- $\quad$ Satisfaction to find P.

- $\quad$ Satisfaction to buy P.

- $\quad$ Satisfaction to use P.

- $\quad$ Satisfaction to have P.

Desirable sensations in e-commerce use

The eCmer does not always know about a product and/or service. Even more, he does not know what he needs and/or wants. Search, offer, and purchase of products from the description of needs is convenient.

- $\quad$ Pleasure to look for P.

- $\quad$ Pleasure to locate P.

Pleasure to buy P.

\section{Conclusions}

This paper presented a description of the elementary aspect of e-commerce. The salepurchase cycle is shown together with some formal elements that support the reflection of this paper. The role of the consumer in the market is evident in the sale-purchase cycle and this is the basis on which transactions are justified in the market. Also, here is notorious that its relevant to pay special attention to all negotiation points in the sale-purchase process because it gives positive product support with consumer and social media. The answer to the question "What does the e-consumer want" is presented and it considers different aspect as security, product, payment methods, etc. to attend the question. This work is relevant because shows the $e$-commerce scenario taking the $e$-consumer as the principal protagonist and the reflection can be extended to general commerce.

\section{References}

Adaji, I., Oyibo, K., \& Vassileva, J. (2018). Consumers' Need for Uniqueness and the Influence of Persuasive Strategies in Ecommerce. In J. Ham, E. Karapanos, P. Morita , \& C. Burns, 13th International Conference on Persuasive Technology (Vol. 10809, pp. 279284). Waterloo, Canada: Springer, Cham.

Amado, A., Cortez, P., Rita, P., \& Moro, S. (2018). Research trends on Big Data in Marketing: A text mining and topic modeling based literature analysis. European Research on Management and Business Economics, 24(1), 17.

Anissa, N. N., Purwandari, B., Wilarso, I., \& Sensuse, D. (n.d.). Factors and Strategies Affecting Consumers' Purchase Intention in B2C e-Commerce.

Aristizábal García, D. M. (2020). 87 Estudios sociales sobre el consumo. Trayectorias disciplinares de uncampo de estudio en construcción. Revista de Estudios Sociales, 71, 87-99.

Barkatullah, A. H., \& Djumadi . (2018, JulyAugust). Does self-regulation provide legal protection and security to e-commerce consumers? Electronic Commerce Research and Applications, 30, 94-101. 
Behera, R. K., Gunasekaran, A., Gupta, S., \& Kamboj , S. (2019, March). Personalised Digital Marketing Recommender Engine. Journal of Retailing and Consumer Services.

Blazquez, M., Zhang, T., Boardman, R., \& Henninger, C. E. (2019). Exploring the Effects of Social Commerce on Consumers' Browsing Motivations and Purchase Intentions in the UK Fashion Industry. In R. Boardman , M. Blazquez , C. Henninger, \& D. Ryding, Social Commerce Consumer Behaviour in Online Environments (pp. 99-115). Online: Palgrave Macmillan, Cham.

Carmona, C. J., Ramírez-Gallego, S., Torres Ruiz, F. J., \& Bernal, E. (2012, September). Web usage mining to improve the design of an ecommerce website: OrOliveSur.com. Expert Systems with Applications, 39(12), 1124311249.

Collins, M. (. (2008). Electronic Resource Management Systems (ERMS) Review. Serials Review, 34(4), 267-299.

Dhamacharoen, A., Kumpusiri, P., \& Waiyakarn, S. (2019). Consumers Perceptions Towards Buying Evaluation and Perceived Risks of E-Commerce Products: A Study on Influencing Factors. Retrieved May 2020, from SSRN:

https://papers.ssrn.com/sol3/papers.cfm?abstrac t_id=3316930

González, N., \& Nava González, W. (2020). Los mecanismos extrajudiciales de resolución de conflictos en línea: su problemática en el derecho internacional privado. $A C D I, 13,187-$ 208.

González-Castolo, J. C., Ramos-Cabral, S., \& Hérnandez-Gallardo, S. C. (2016, Jul-Dic). Reflections of relationship in Information and Communication Technology by Small and Medium Enterprises of Pottery Industry in Jalisco, Mexico. Revista Iberoamericana de Contaduría, Economía y Administración. ISSN 2007-9907, 5, 1-19.

Ilmudeen , A. (2019). SSRN. Retrieved May 2020 , from https://papers.ssrn.com/sol3/papers.cfm?abstrac t_id=3344618
Jimenez Villalba, J. A., \& Moreno Acevedo, J. (2020). Implementación de diseño de interiores virtual en la plataforma de Muebles Jamar para aumentar el ticket de ventas. Colombia.

Kotsuka, Y., Murakami, R., \& Arima, S. (2019). Development and Evaluation of Chat-bot Systems: The Applications of Citizen Service Procedures,. 8th International Congress on Advanced Applied Informatics (IIAI-AAI), 290295.

Licona Michel, Á., Rangel Delgado, J., \& González García, J. (2020). Reflexiones sobre el proceso de integración de la Alianza del Pacífico desde la perspectiva de la competitividad e inversión en ciencia y tecnología: retos para la integración comercial futura. México y la Cuenca del Pacífico, 9(25), 23-49.

Liébana-Cabanillas, F., Muñoz-Leiva, F., Sánchez-Fernández, J., \& Viedma-del Jesús, M. I. (2016, February). The moderating effect of user experience on satisfaction with electronic banking: empirical evidence from the Spanish case. Syst E-Bus Manage, 14, 141-165.

Lingyun, Q., \& Dong, L. (2008, June). Applying TAM in B2C E-commerce research: An extended model. Tsinghua Science and Technology, 13(3), 265-272.

Linwan, W. (2019, July). Website interactivity may compensate for consumers' reduced control in E-Commerce. Journal of Retailing and Consumer Services, 49, 253-266.

Luo, X. R., Xu, H., \& Yao, L. J. (2012, June). Ecommerce intelligence development and research in the Greater China Region. Electron Markets, 22, 71-72.

MD, CCFP, Ratnapalan, S., Lam-Antoniades, M., \& Tait, G. (2009, September). Electronic Continuing Education in the Health Professions: An Update on Evidence from RCTs. Journal of Continuing Education in the Health Professions, 29, 44-51.

O'Leary, D. (2000, April). Reengineering Assembly, Warehouse and Billing Processes, for Electronic Commerce Using "Merge-inTransit". Information Systems Frontiers, 1, 379387. 
Pesántez Calva, A. E., Romero Correa, J. A., \& González Illescas, M. L. (2020). Comercio electrónico B2B como estrategia competitiva en el comercio internacional: Desafíos para Ecuado. INNOVA Research Journal,, 5(1), 7293.

Shen, L., Zhou, Y., Xu, C., Hu, X., \& Hu, B. (2009, December). Predicting User Behavior in E-commerce Based on Psychology Model. Sixth International Conference on Fuzzy Systems and Knowledge Discovery, , 576-580.

Tekin, M., Etlioglu, M., Koyuncuoğlu, Ö., \& Tekin, E. (2018). Data Mining in Digital Marketing. Proceedings of the International Symposium for Production Research, 44-61.

Wrenn, K., Catschegn, S., Cruz, M., Gleason, N., \& Gonzales, R. (2017, February). Analysis of an electronic consultation program at an academic medical centre: Primary care provider questions, specialist responses, and primary care provider actions. Journal of telemedicine and telecare, 23(2), 217-224. 